\title{
Pumpkin and Carrot Pomace Powders as a Source of Dietary Fiber and Their Effects on the Mixing Properties of Wheat Flour Dough and Cookie Quality
}

\author{
Secil TuRKSOY* and Berrin ÖZKAYA \\ Ankara University, Faculty of Engineering, Department of Food Engineering, Diskapi Campus 06110 Diskapi, Ankara - TURKEY
}

Received December 14, 2010; Accepted August 30, 2011

In the present study, it was aimed to enrich standard cookie recipe by addition of pumpkin (Cucurbita moschat Duch. ex. Poir.) pomace powder (PPP) and carrot (Daucus carota L.) pomace powder (CPP). Two different soft wheat flour (Gerek-79 and Guadalupe) were substituted by 4 levels of PPP and CPP (10\%, $15 \%, 20 \%$ and $25 \%$ ) and the effects of increased levels of PPP and CPP on the farinogram properties of wheat flour dough and chemical composition, physical, textural and organoleptic properties of cookies were investigated. Addition of PPP and CPP increased water absorption (approximately 1.5 times), stability and development time as measured by farinograph. Cookies supplemented with PPP and CPP became darker with increasing levels of fiber and the creamy-yellow color of the control samples turned into orange-yellow. Addition of PPP and CPP decreased the spread ratio but increased breaking strength of cookies. Enriched cookies exhibited 1.5-2 times strength than control. In consideration of the results of sensory evaluation, it can be concluded that overall acceptability values decreased depending on increasing levels of PPP and CPP. Highly acceptable cookies could be obtained by incorporating PPP and CPP in both flour samples.

Keywords: pumpkin, carrot, dietary fiber, mixing properties, cookie quality

\section{Introduction}

Dietary fibers which positively affect specific physiological functions in human body improve our general state of health. The healthful properties of dietary fibers have caused an increase consumption of high-fiber food products and encouraged food scientists to search for new fiber sources as food ingredients (Chau et al., 2004; Yoon et al., 2005).

Consumption of vegetables has increased and been associated with a lower risk of degenerative diseases. Cereal brans which are more common dietary fiber sources have generally negative effects on quality and organoleptic properties of the end product. In addition, higher phytic acid content which is an important problem in cereal bran can block the absorption of trace minerals and cause malnutrition. Although dietary fibers from cereals is more frequently used than fiber from vegetables, fiber concentrates obtained vegetables can be used in the food industry as functional ingredients. However, vegetable fibers have better quality due

*To whom correspondence should be addressed.

E-mail: turksoy@eng.ankara.edu.tr to it's higher soluble dietary fiber content, better water holding capacities and lower phytic acid contents. Beside these, vegetables have also contained various bioactive substances such as antioxidants, polyphenols and carotenoids (Cao et al., 1996; Eim et al., 2008).

Among vegetables, carrot (Daucus carota L.) and pumpkin (Cucurbita moschat Duch. ex. Poir.) are being considered as good examples of functional foods. They are also most promising foods due to their pleasant flavor, and higher contents of vitamin, mineral, dietary fiber, natural antioxidants, carotenoids and phenolic compounds (Ptitchkina et al., 1998; Alasalvar et al., 2001; Chau et al., 2004; Escalada Pla et al., 2006; Chantaro et al., 2008). As an important vegetable, carrot has usually been used for juice production. Thus large amounts of carrot pomace have been produced after juice production. Many studies have also reported that dietary fibers can be produced from fiber-rich agricultural by-products of vegetables (Rehman et al., 2003; Chau et al., 2004; Yoon et al., 2005). Pumpkin coming from tropical and subtropical zones has also been receiving an increasing attention due to its nutritional value, low polysaccharides content and 
low energy value of the fruit and the oil content of the seeds (Evageliolu et al., 2005; Jun et al., 2005; Caili et al., 2007; Aziah and Komathi, 2009; Gliemmo et al., 2009). Evageliou et al. (2005) indicated that the pressed pulp remaining after extraction of juice from pumpkins seemed a promising source of dietary fiber for domestic use in Russia.

In previous studies, pumpkin was generally used in formulations as it was or pomace. In this case, undesirable pumpkin flavor tends to pass to the cookies. As mentioned above, in the study pomace which remains after the extraction of pumpkin and carrot juice was washed. So, transfer of pumpkin and carrot flavor to the cookies was tried to reduce as much as possible. Besides, pomace has become more concentrated as a result of the separation of sugar and water soluble compounds.

Cookies are widely accepted and consumed nearly by all parts of the world due to its ready to eat nature, good nutritional quality, affordable cost and availability in different taste and longer shelf life (Arshad et al., 2007; Sudha et al., 2007a; Ajila et al., 2008). According to all positive attributes, cookies have become focus of interest as a source of incorporation of different ingredients.

In the light of such information, it is clear that incorporation of carrot and pomace powders would improve the nutritional value of cookies. However, very little information is available in the literature regarding the carrot and pumpkin pomace powders as fiber sources in cookie formulation. Therefore, the present study was aimed to investigate the usage of carrot and pumpkin pomace powders in the preparation of wire-cut type cookies and the effects of carrot and pomace powders incorporation at different levels on mixing properties of wheat flour dough and on the chemical composition, quality characteristics and sensory properties of cookies.

\section{Materials and Methods}

Material In the study, two soft wheat varieties (Gerek-79 and Guadalupe) which were different in terms of protein and gluten contents were used as material. They were obtained from the General Directories of Agricultural Enterprises (Malya and Hatay, Turkey). After tempering to $15.0 \%$, they were milled to produce particles with a size $148 \mu \mathrm{m}$ on a standard laboratory mill (Buhler Bros Inc. Uzvil, Switzerland) (Özkaya and Özkaya, 2005).

Pumpkins (Arıcan-97) and carrots (Nanco) were obtained from Ayaş Horticulture Research and Application Farm (Ankara, Turkey) and Beypazarı (Ankara, Turkey), respectively.

Pumpkin and carrot pomace powder production PPP and CPP were prepared according to the method described by Figuerola et al. (2005) with some modifications. After being washed in cold tap water, pumpkin and carrot samples were peeled and chopped into thin pieces. The juice of pumpkin and carrot pieces were extracted by a juice extractor (Le Duo, Magimix, UK). The pumpkin and carrot pomaces which remain after the extraction of juice were washed with distilled water at $20^{\circ} \mathrm{C}$ to reduce sugar and water soluble contents. So, transfer of pumpkin and carrot flavor to the cookies was tried to reduce as much as possible. Then pomace dried at $50^{\circ} \mathrm{C}$ in a forced-air oven for $8 \mathrm{~h}$. until 12\% moisture content. After the dried samples were powdered using a laboratory mill (Falling Number Type 120) to produce particles with a size $425 \mu \mathrm{m}$, they were stored in polyethylene bags for further analysis. Yields of PPP and CPP from raw pumpkin (unpeeled) and carrot are $7 \%$ and $5 \%$, respectively. Blends of $0,10,15,20$ and $25 \%$ were prepared by substituting wheat flour with PPP and CPP.

Chemicals Sugar, non-fat dry milk and salt, which was used in the formulation cookie dough were purchased from a local market while shortening and high fructose corn syrup (HFCS) were obtained from a commercial cookie factory (Ülker Gıda A. Ş., Ankara, Turkey). Ammonium and sodium bicarbonate used in the formulation were of food grade. All other reagents were of analytical grade.

Chemical analyses Moisture and ash contents of raw materials and cookie samples were determined according to the ICC Standard Method 110/1 and 104/1, respectively (ICC, 2002). Protein content was determined using Approved Method No: 46-12 (AACC, 2002) and it was expressed as nitrogen multiplied by a factor depending on the type of material (5.7 for wheat flour, 6.25 for PPP and CPP). Total (TDF), soluble (SDF) and insoluble (IDF) dietary fiber contents of flour, PPP, CPP and cookie samples were determined according to AOAC Method No: 991.43 (AOAC, 2000).

The effect of pomace powders on cookie dough properties were evaluated by using farinograph (Brabender $\mathrm{OGH}$, Duisburg, Germany) according to the ICC Standard Method 115/1 (ICC, 2002). The measured farinograph parameters were water absorption, dough development time, dough stability and degree of softening.

Cookie making The baking process of cookies was carried out for blends of $0 \%, 10 \%, 15 \%, 20 \%$ and $25 \%$, which were prepared by substituting flours in the cookie formulation with PPP and CPP, according to the "wire-cut cookie" method No. 10-54 (AACC, 2002). The formula used was: 40 $\mathrm{g}$ flour, $16.8 \mathrm{~g}$ icing sugar, $16 \mathrm{~g}$ shortening, $0.4 \mathrm{~g}$ nonfat dry milk, $0.5 \mathrm{~g}$ salt, $0.4 \mathrm{~g}$ sodium bicarbonate, $0.6 \mathrm{~g}$ HFCS, 0.2 $\mathrm{g}$ ammonium bicarbonate and [(40-g flour $)+8.8] \mathrm{mL}$ water. After baking, cookies were cooled at room temperature and were packed in polypropylene pouches and sealed until further analysis. 


\section{Evaluation of cookie quality}

Physical characteristics The physical characteristics (diameter, thickness, spread ratio) of cookie samples were determined according to the AACC Approved Method No 10-50D (AACC, 2002) and the evaluation of texture expressed as breaking strength was measured by using the three point bend rig technique by a texture analyzer (TA-TX2i Plus, Stable Micro System Surrey, UK; Pre-test speed 1.00 $\mathrm{mm} / \mathrm{sec}$; test speed $3.00 \mathrm{~mm} / \mathrm{sec}$; post-test speed $10.00 \mathrm{~mm} /$ $\mathrm{sec}$; distance sensitivity $5 \mathrm{~mm}$; trigger force $50 \mathrm{~g}$ ) (Gaines, 1991).

Color measurement of cookies The surface color, L* (brightness), a* (redness) and $b^{*}$ (yellowness) values of cookie samples were measured using a Hunter Color Measuring System (Konica Minolta, Model CR400, Japan) (Anonymous, 2002). Average of six values was taken (5 side, 1 center of cookie) for each group of sample.

Sensory evaluation of cookies Cookie samples were evaluated for surface color, crust appearance, texture, taste and overall acceptability. The samples, which were coded with different numbers, were presented to 12 panelists under room temperature and white light. A 1-5 hedonic scale was used to evaluate the samples and panelists rated each sensory attribute between 1 point (unacceptable) and 5 point (very well). Average of values was taken for each panelist.

Statistical analysis In the experiments conducted, the effects of addition level related to the kind of pomace powder on the cookie characteristics were examined. A factorial experimental design $(2 \times 2 \times 4=16)$ was used to evaluate the cookie properties. There were two varieties of flour $x$ two types of pomace powder $\mathrm{x}$ four levels of each pomace powder substitutions times. All analyses were done in triplicate and recorded as means of \pm SE. Data were analysed by SPSS for Windows (ver. 10.0, Illiniois, U.S.A.) using two-way analysis of variance (ANOVA) and Duncan comparisons were done to test any significant differences between samples $(\mathrm{P}<0.05)$. Sensory evaluation scores were not normally distributed and were hence subjected to the non 192 parametric Kruskall-Wallis test.

\section{Results and Discussion}

Chemical composition The contents of moisture, ash, protein and dietary fiber (total, soluble and insoluble) of flour, PPP and CPP are shown in Table 1. It can be seen that among the values in the table, the ash, TDF, SDF and IDF contents of pomace powder samples were much higher than that of flour samples. Accordingly, it is understood that the PPP and CPP are considerably rich in dietary fiber. It is indicated that when the rate of SDF/IDF is approximately $1 / 2$ in the fiber sources to be used as food ingredient or when there is approximately $30-50 \% \mathrm{SDF}$ and $50-70 \%$ IDF within the total dietary fiber, it is a good balance for health (Schneeman, 1987; Jaime et al., 2002). It could be stated that the PPP and CPP has a good balance an excellent nutrition quality from that aspect. Despite the protein content of CPP was lower than flour samples, it was found similar to flours for PPP.

The effect of the pumpkin and carrot pomace powders addition on the farinogram characteristics of the dough The effect of pumpkin and carrot pomace powders substitution levels on farinogram characteristics of the flour samples are illustrated in Figure 1. Incorporation of both pumpkin and carrot pomace powder to the flour samples caused great changes in farinogram properties. There was a progressive increase in water absorption with increasing levels of PPP and CPP addition; probably due to the richness of dietary fiber of these vegetables. The water absorption increased 56\% (PPP) and 55\% (CPP) for Gerek-79 flour sample and 36\% (PPP) and 41\% (CPP) for Guadalupe flour sample depending

Table 1. The chemical and dietary fiber composition of flour, PPP and CPP.

\begin{tabular}{|c|c|c|c|c|}
\hline \multirow{2}{*}{ Component } & \multicolumn{2}{|c|}{ Wheat flour } & \multirow{2}{*}{ PPP } & \multirow{2}{*}{$\mathrm{CPP}$} \\
\hline & Gerek-79 & Guadalupe & & \\
\hline Moisture (\%) & $10.50 \pm 0.88^{a}$ & $10.60 \pm 1.03^{\mathrm{a}}$ & $6.24 \pm 1.08^{b}$ & $6.80 \pm 1.23^{b}$ \\
\hline $\operatorname{Ash}^{*}(\%)$ & $0.45 \pm 0.03^{a}$ & $0.48 \pm 0.08^{\mathrm{a}}$ & $4.78 \pm 0.68^{b}$ & $5.26 \pm 1.01^{\mathrm{c}}$ \\
\hline Total protein ${ }^{(*)(* *)}(\%)$ & $13.20 \pm 0.50^{\mathrm{c}}$ & $11.30 \pm 0.64^{\mathrm{b}}$ & $11.09 \pm 0.08^{b}$ & $4.93 \pm 0.75^{\mathrm{a}}$ \\
\hline Wet gluten $(\%)$ & $37.50 \pm 0.08^{b}$ & $28.30 \pm 0.12^{\mathrm{a}}$ & - & - \\
\hline Total dietary fiber ${ }^{*}(\%)$ & $2.02 \pm 0.35^{\mathrm{a}}$ & $2.15 \pm 0.42^{\mathrm{a}}$ & $76.94 \pm 2.10^{\mathrm{c}}$ & $73.00 \pm 0.90^{b}$ \\
\hline Soluble dietary fiber ${ }^{*}(\%)$ & $0.82 \pm 0.02^{\mathrm{a}}$ & $0.25 \pm 0.01^{\mathrm{a}}$ & $19.25 \pm 0.76^{\mathrm{c}}$ & $15.38 \pm 1.11^{b}$ \\
\hline Insoluble dietary fiber ${ }^{*}(\%)$ & $1.20 \pm 0.32^{\mathrm{a}}$ & $1.90 \pm 1.10^{\mathrm{a}}$ & $57.69 \pm 2.32^{b}$ & $57.62 \pm 1.92^{b}$ \\
\hline
\end{tabular}

All data are the mean $\pm \mathrm{SD}$ of three replicates.

* dry basis

${ }^{* *}$ Flour: $\mathrm{N} \times 5.70$, PPP and CPP: $\mathrm{N} \times 6.25$

PPP:Pumpkin pomace powder, CPP: Carrot pomace powder

Means followed by a-c letters in the same row for each component are significantly different $(\mathrm{P} \leq 0.05)$. 

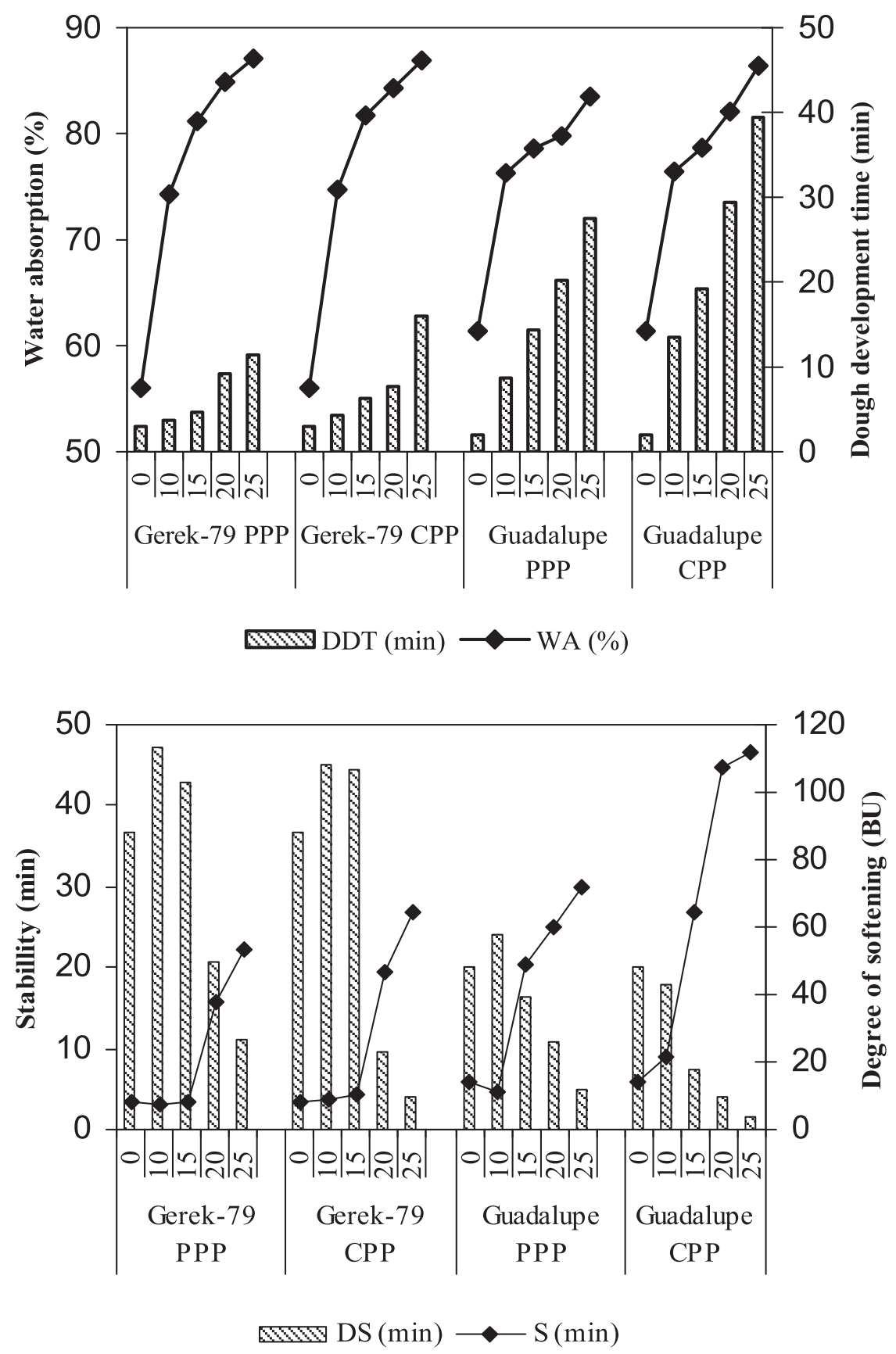

Fig. 1. Effects of PPP and CPP addition on farinogram characteristics.

on the dietary fiber source and increased dietary fiber level. It was determined that the water absorption considerably increased in the previous researches, which were carried out by adding cereal bran, mango peel powder and apple fiber, which had high level of dietary fiber (Sudha et al., 2007b; Ajila et al., 2008). It was indicated that the increase in the water absorption was caused by the hydrogen bonds, which are constituted as a result of the interaction of hydroxyl groups within the structure of the dietary fiber components with water (Gómez et al., 2003; Dikeman and Fahey, 2006; Rosell et al., 2009).
Besides the change of water absorption mentioned above, it was observed a significant increase in the dough development time. It increased from $3.0 \mathrm{~min}$ to $11.4 \mathrm{~min}$ for Gerek-79 and from $2.0 \mathrm{~min}$ to $27.5 \mathrm{~min}$ for Guadalupe with the addition of PPP at the rate of $25 \%$; while it raised from $3.0 \mathrm{~min}$ to $16.0 \mathrm{~min}$ for Gerek-79 and from $2.0 \mathrm{~min}$ to 39.4 min for Guadalupe for the addition of CPP. It was observed a steady increase in stability, which indicates the resistance of the dough, with the addition of PPP and CPP from 10\% to $25 \%$ level. However, they decreased the softening degree. The fact that the PPP and CPP decreased the degree of soft- 
ening value was probably caused by greater water absorption and lower weakening effects of dietary fiber sources (Larrea et al., 2005; Sudha et al., 2007b; Ajila et al., 2008).

Evaluation of the cookies, containing the pumpkin and carrot pomace powders Color characteristics of the cookies The color of cookies which is one of the characteristics affects the acceptability of end product by the consumer. The effect of the PPP and CPP on the color characteristics of cookies are given in Figure 2 and Table 2. Since the PPP and CPP contain too much $\beta$-carotene, they have an orange color (Lee et al., 2002; Pongjanta et al., 2006; Chantaro et al., 2008). Therefore, when PPP or CPP were added to the flour, cookies became darker and the creamy-yellow color of the control samples turned into orange-yellow when they were added at the rate of $25 \%$.

In general, PPP and CPP addition at $10 \%$ to $25 \%$ cookie samples considerably decreased the ' $L$ ' values which indicate the brightness, and increased the ' $a$ ' values, showing the redness. The ' $b$ ' values which indicate the yellowness of all cookies supplemented with PPP were higher than of the control samples. No remarkable difference in this value of cookies containing PPP was observed. However, addition at CPP to the cookie samples decreased the ' $b$ ' values depending on the increasing level of supplement. Similar results

\section{Gerek - 79}

\section{Fibre Level (\%)}

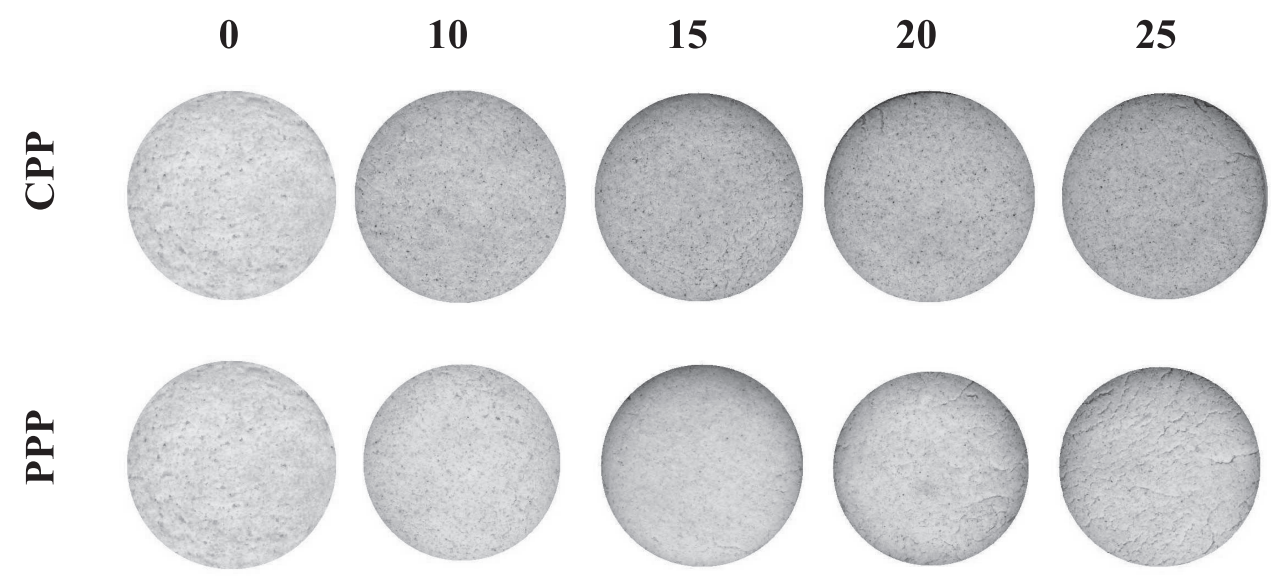

\section{Guadalupe}

Fibre Level (\%)
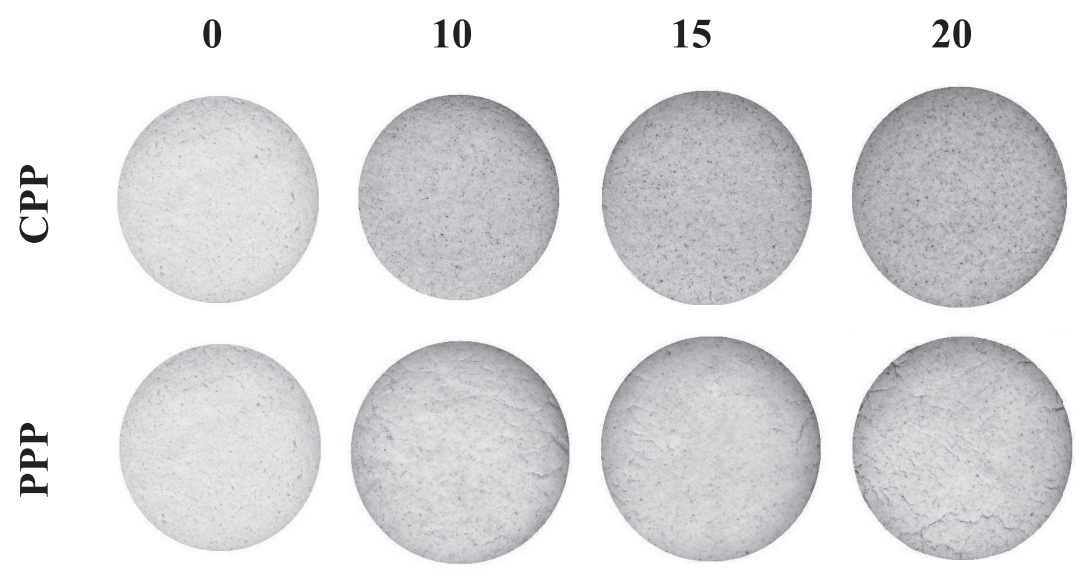

25

Fig. 2. Photographs of cookies supplemented with PPP and CPP. 
Table 2. Effects of PPP and CPP substitution levels on the L, a, b values of cookies.

\begin{tabular}{|c|c|c|c|c|c|}
\hline Flour & Fiber source & Fiber level (\%) & 'L' Value & 'a' Value & 'b' Value \\
\hline \multirow{10}{*}{ 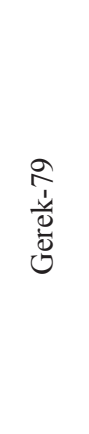 } & \multirow{5}{*}{ PPP } & 0 & $64.84 \pm 0.40^{\mathrm{bAx}}$ & $0.80 \pm 0.33^{\mathrm{aAx}}$ & $22.56 \pm 0.10^{\mathrm{aBx}}$ \\
\hline & & 10 & $66.02 \pm 0.59^{\mathrm{cCx}}$ & $3.51 \pm 0.31^{\mathrm{bBCy}}$ & $24.92 \pm 0.03^{\mathrm{bBx}}$ \\
\hline & & 15 & $65.67 \pm 0.28^{\mathrm{cBx}}$ & $4.47 \pm 0.26^{\text {bcBy }}$ & $25.07 \pm 0.07^{\mathrm{cBx}}$ \\
\hline & & 20 & $64.71 \pm 0.27^{\mathrm{bBx}}$ & $4.88 \pm 0.19^{\mathrm{bcBCy}}$ & $25.29 \pm 0.11^{\mathrm{bcBx}}$ \\
\hline & & 25 & $62.57 \pm 0.21^{\mathrm{aCx}}$ & $5.85 \pm 0.08^{\mathrm{cCy}}$ & $25.89 \pm 0.13^{\mathrm{dBx}}$ \\
\hline & \multirow{5}{*}{$\mathrm{CPP}$} & 0 & $64.84 \pm 0.40^{\mathrm{eAx}}$ & $0.80 \pm 0.33^{\mathrm{aAx}}$ & $22.56 \pm 0.10^{\mathrm{aBx}}$ \\
\hline & & 10 & $59.03 \pm 0.33^{\mathrm{dAx}}$ & $3.25 \pm 0.16^{\mathrm{bBx}}$ & $20.10 \pm 0.09^{\mathrm{bAx}}$ \\
\hline & & 15 & $56.18 \pm 0.34^{\mathrm{cAx}}$ & $4.49 \pm 0.15^{\mathrm{cBx}}$ & $20.08 \pm 0.05^{\mathrm{bAx}}$ \\
\hline & & 20 & $55.06 \pm 0.16^{\mathrm{bAx}}$ & $4.80 \pm 0.12^{\mathrm{cBx}}$ & $19.45 \pm 0.14^{\mathrm{aAx}}$ \\
\hline & & 25 & $53.53 \pm 0.08^{\mathrm{aAx}}$ & $5.03 \pm 0.04^{\mathrm{cBx}}$ & $19.12 \pm 0.09^{\mathrm{aAx}}$ \\
\hline \multirow{10}{*}{$\frac{\stackrel{0}{\Xi}}{\frac{\tilde{J}}{\tilde{J}}}$} & \multirow{5}{*}{ PPP } & 0 & $70.32 \pm 0.98^{\mathrm{aBy}}$ & $1.05 \pm 0.57^{\mathrm{aBy}}$ & $22.14 \pm 0.41^{\mathrm{aAx}}$ \\
\hline & & 10 & $70.17 \pm 0.32^{\mathrm{aDy}}$ & $2.57 \pm 0.19^{\mathrm{bAx}}$ & $25.20 \pm 0.05^{\mathrm{bCx}}$ \\
\hline & & 15 & $68.96 \pm 0.28^{\mathrm{aCy}}$ & $3.19 \pm 0.17^{\mathrm{bcAx}}$ & $25.56 \pm 0.04^{\mathrm{bCx}}$ \\
\hline & & 20 & $66.90 \pm 0.19^{\mathrm{bCy}}$ & $3.63 \pm 0.15^{\mathrm{cAx}}$ & $25.56 \pm 0.16^{\mathrm{bCx}}$ \\
\hline & & 25 & $65.68 \pm 0.32^{\mathrm{bDy}}$ & $4.49 \pm 0.08^{\mathrm{dAx}}$ & $26.56 \pm 0.16^{\mathrm{cCx}}$ \\
\hline & \multirow{5}{*}{ CPP } & 0 & $70.32 \pm 0.98^{\mathrm{aBy}}$ & $1.05 \pm 0.57^{\mathrm{aBy}}$ & $22.14 \pm 0.41^{\mathrm{cAx}}$ \\
\hline & & 10 & $60.89 \pm 0.39^{\mathrm{bBx}}$ & $3.87 \pm 0.05^{\mathrm{bCx}}$ & $20.39 \pm 0.01^{\mathrm{bAx}}$ \\
\hline & & 15 & $57.93 \pm 0.33^{\mathrm{cAx}}$ & $4.46 \pm 0.12^{\mathrm{bcBx}}$ & $19.93 \pm 0.05^{\mathrm{abAx}}$ \\
\hline & & 20 & $56.55 \pm 0.20^{\mathrm{cdAx}}$ & $4.90 \pm 0.11^{\mathrm{cCx}}$ & $19.55 \pm 0.10^{\mathrm{aAx}}$ \\
\hline & & 25 & $54.92 \pm 0.25^{\mathrm{dBx}}$ & $4.94 \pm 0.07^{\mathrm{cBx}}$ & $19.38 \pm 0.07^{\mathrm{aAx}}$ \\
\hline
\end{tabular}

All data are the mean $\pm \mathrm{SE}$ of three replicates.

L: Lightness, a: Redness, b: Yellowness., PPP: Pumpkin Pomace Powder, CPP: Carrot Pomace Powder.

Means followed by a-d letters in the same column for each fiber source are significantly different $(\mathrm{P} \leq 0.05)$.

Means followed by A-D letters in the same column for each fiber addition level are significantly different $(\mathrm{P} \leq 0.05)$.

Means followed by $\mathrm{x}-\mathrm{y}$ letters in the same column for each flour type are significantly different $(\mathrm{P} \leq 0.05)$.

were obtained in a previous studies, performed on the cookie samples containing the mango peel powder (Ajila et al., 2008) and pumpkin powder (Lee et al., 2002; Pongjanta et al., 2006).

Physical properties of the cookies The effects of the PPP and CPP addition at different levels on the physical properties such as diameter, thickness, spread ratio and breaking strength of cookies are summarised in Table 3. A regular decrement was observed in the diameter of all cookie samples supplemented with PPP and CPP. In addition to this, cookies containing PPP or CPP exhibited more thickness value than control and cookie thickness were slightly increased with the addition of these supplements. Decrement of diameter and increment of thickness led to reduce the spread ratio values of cookie samples supplemented with PPP and CPP. It can be interpreted that PPP and CPP used in the cookie formulations affected the spread ratio values due to high water absorption capacity of PPP and CPP. It was expressed that the ingredients, which absorb water during dough mixing, increase the dough viscosity and limit the cookie spread (McWatters et al., 2003; Arshad et al., 2007). There are various researches aimed to understand the mechanism of reducing the diameter of cookies when wheat flour supplemented with non-wheat flours. Beside this it was also reported that increasing fiber addition reduced the spread ratio of highfiber cookies (Seker et al., 2009).

The cookies incorporated PPP and CPP were significantly harder than the control samples $(P \leq 0.05)$. As a result of this, the breaking strength values of all cookie samples were higher approximately 1.5-2 times than control samples. The increment of hardness probably related to the amount of PPP and CPP added and their high water holding capacity. Similar results were indicated by the others. The researchers indicated that the factors, which increased the water content of the dough, constituted the extensive gluten structure and stiffened the cookies; consequently, the breaking strength of the cookies increased (Gaines, 1991; Arora and Camire, 1994; Larrea et al., 2005; Ajila et al., 2008).

Sensory characteristics of the cookies The cookies made from Gerek-79 and Guadalupe flour supplemented with PPP and CPP at different levels, were exposed to sensory evaluation, in accordance with the characteristics of crust color, crust appearance, texture, taste-flavor and overall acceptability and the average values of panelist scores are given in Table 4. Each parameter was evaluated within the 1 (unacceptable) and 5 (very good) score interval. 
Table 3. Effects of PPP and CPP addition on the physical characteristics of cookies.

\begin{tabular}{|c|c|c|c|c|c|c|}
\hline Flour & Fiber source & Fiber level (\%) & $\begin{array}{l}\text { Diameter } \\
(W, \mathrm{~mm})\end{array}$ & $\begin{array}{l}\text { Thickness } \\
(T, \mathrm{~mm})\end{array}$ & $\begin{array}{l}\text { Spread ratio } \\
(W / T)\end{array}$ & $\begin{array}{c}\text { Breaking strength } \\
\qquad(F, \mathrm{~N})\end{array}$ \\
\hline \multirow{10}{*}{$\frac{2}{\frac{1}{0}}$} & \multirow{5}{*}{ PPP } & 0 & $81.79 \pm 0.14^{\mathrm{dBy}}$ & $8.95 \pm 0.03^{\mathrm{aAx}}$ & $9.14 \pm 0.03^{\mathrm{eBy}}$ & $9.08 \pm 0.22^{\mathrm{aBy}}$ \\
\hline & & 10 & $69.57 \pm 0.78^{\mathrm{cCy}}$ & $11.63 \pm 0.11^{\mathrm{bBx}}$ & $5.98 \pm 0.05^{\mathrm{dABx}}$ & $15.96 \pm 1.43^{\mathrm{bCy}}$ \\
\hline & & 15 & $65.87 \pm 0.55^{\mathrm{bBy}}$ & $11.82 \pm 0.04^{\mathrm{bcAx}}$ & $5.57 \pm 0.04^{\mathrm{cAx}}$ & $16.97 \pm 0.78^{\text {bDy }}$ \\
\hline & & 20 & $63.84 \pm 0.27^{\mathrm{aBy}}$ & $11.88 \pm 0.11^{\mathrm{cdBx}}$ & $5.37 \pm 0.06^{\mathrm{bBx}}$ & $17.22 \pm 0.37^{\text {bDy }}$ \\
\hline & & 25 & $62.76 \pm 0.08^{\mathrm{aABy}}$ & $12.09 \pm 0.04^{\mathrm{dBx}}$ & $5.19 \pm 0.01^{\mathrm{aAx}}$ & $18.55 \pm 0.62^{\text {bDy }}$ \\
\hline & \multirow{5}{*}{ СРP } & 0 & $81.79 \pm 0.14^{\mathrm{dBy}}$ & $8.95 \pm 0.03^{\mathrm{aAx}}$ & $9.14 \pm 0.03^{\mathrm{dBy}}$ & $9.08 \pm 0.22^{\mathrm{aBy}}$ \\
\hline & & 10 & $72.44 \pm 0.64^{\mathrm{cDy}}$ & $10.63 \pm 0.10^{\mathrm{bAx}}$ & $6.81 \pm 0.08^{\mathrm{cBy}}$ & $10.03 \pm 0.16^{\mathrm{abBy}}$ \\
\hline & & 15 & $68.21 \pm 0.45^{\mathrm{bCy}}$ & $11.14 \pm 0.11^{\mathrm{cAx}}$ & $6.11 \pm 0.05^{\mathrm{bBy}}$ & $10.42 \pm 0.21^{\mathrm{abBy}}$ \\
\hline & & 20 & $65.92 \pm 0.29^{\mathrm{aCy}}$ & $11.57 \pm 0.17^{\mathrm{dAx}}$ & $5.70 \pm 0.10^{\mathrm{aBx}}$ & $11.01 \pm 0.23^{\mathrm{bcBy}}$ \\
\hline & & 25 & $65.27 \pm 0.24^{\mathrm{aCy}}$ & $11.64 \pm 0.13^{\mathrm{dAx}}$ & $5.60 \pm 0.08^{\mathrm{aBx}}$ & $12.14 \pm 0.86^{\mathrm{cBx}}$ \\
\hline \multirow{10}{*}{ 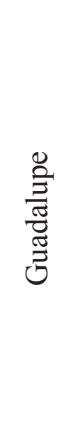 } & \multirow{5}{*}{ PPP } & 0 & $73.84 \pm 0.13^{\mathrm{cAx}}$ & $10.72 \pm 0.02^{\mathrm{aBy}}$ & $6.88 \pm 0.01^{\mathrm{cAx}}$ & $8.66 \pm 0.17^{\mathrm{aAx}}$ \\
\hline & & 10 & $64.45 \pm 0.10^{\mathrm{bAx}}$ & $12.18 \pm 0.03^{\mathrm{bCy}}$ & $5.29 \pm 0.02^{\mathrm{bAx}}$ & $10.19 \pm 0.83^{a b B x}$ \\
\hline & & 15 & $63.83 \pm 0.32^{\mathrm{bAx}}$ & $12.23 \pm 0.07^{\mathrm{bAx}}$ & $5.22 \pm 0.03^{\mathrm{bAx}}$ & $12.15 \pm 0.48^{\mathrm{abCx}}$ \\
\hline & & 20 & $61.81 \pm 0.32^{\mathrm{aAx}}$ & $12.27 \pm 0.06^{\mathrm{bBx}}$ & $5.04 \pm 0.02^{\mathrm{aAx}}$ & $12.34 \pm 1.73^{\mathrm{abCx}}$ \\
\hline & & 25 & $61.72 \pm 0.14^{\mathrm{aAx}}$ & $12.33 \pm 0.12^{\mathrm{bBx}}$ & $5.00 \pm 0.05^{\mathrm{aAx}}$ & $13.08 \pm 1.42^{\mathrm{bCx}}$ \\
\hline & \multirow{5}{*}{$\mathrm{CPP}$} & 0 & $73.84 \pm 0.13^{\mathrm{eAx}}$ & $10.72 \pm 0.02^{\mathrm{aBy}}$ & $6.88 \pm 0.01^{\mathrm{dAx}}$ & $8.66 \pm 0.17^{\mathrm{aAx}}$ \\
\hline & & 10 & $66.92 \pm 0.20^{\mathrm{dBx}}$ & $11.60 \pm 0.15^{\mathrm{bBy}}$ & $5.77 \pm 0.08^{\mathrm{cAx}}$ & $8.66 \pm 0.64^{\mathrm{aAx}}$ \\
\hline & & 15 & $65.31 \pm 0.45^{\mathrm{cBx}}$ & $11.72 \pm 0.10^{\mathrm{bAx}}$ & $5.57 \pm 0.09^{\mathrm{bcAx}}$ & $8.85 \pm 0.28^{\mathrm{aAx}}$ \\
\hline & & 20 & $64.45 \pm 0.10^{\mathrm{bBCx}}$ & $11.82 \pm 0.14^{\mathrm{bBx}}$ & $5.45 \pm 0.07^{\mathrm{bBx}}$ & $10.02 \pm 1.00^{\mathrm{aAx}}$ \\
\hline & & 25 & $62.94 \pm 0.21^{\mathrm{aBx}}$ & $12.18 \pm 0.10^{\mathrm{cBy}}$ & $5.17 \pm 0.05^{\mathrm{aAx}}$ & $11.88 \pm 0.30^{\mathrm{bAx}}$ \\
\hline
\end{tabular}

All data are the mean $\pm \mathrm{SE}$ of three replicates.

PPP: Pumpkin Pomace Powder, CPP: Carrot Pomace Powder.

Means followed by a-d letters in the same column for each fiber source are significantly different $(\mathrm{P} \leq 0.05)$.

Means followed by A-D letters in the same column for each fiber addition level are significantly different $(\mathrm{P} \leq 0.05)$.

Means followed by $\mathrm{x}-\mathrm{y}$ letters in the same column for each flour type are significantly different $(\mathrm{P} \leq 0.05)$.

Table 4. Effect of PPP and CPP addition on the sensory characteristics of cookies.

\begin{tabular}{|c|c|c|c|c|c|c|c|}
\hline Flour & Fiber source & Fiber level (\%) & Crust color & Crust appearance & Texture & Taste & $\begin{array}{c}\text { Overall } \\
\text { acceptability }\end{array}$ \\
\hline \multirow{10}{*}{ 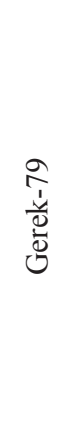 } & \multirow{5}{*}{ PPP } & 0 & $3.5 \pm 0.24$ & $2.9 \pm 0.44$ & $4.5 \pm 0.15$ & $4.5 \pm 0.24$ & $4.5 \pm 0.24$ \\
\hline & & 10 & $3.9 \pm 0.24$ & $4.2 \pm 0.24$ & $4.3 \pm 0.26$ & $3.7 \pm 0.29$ & $3.9 \pm 0.34$ \\
\hline & & 15 & $3.9 \pm 0.25$ & $3.9 \pm 0.18$ & $3.8 \pm 0.33$ & $3.6 \pm 0.32$ & $3.9 \pm 0.40$ \\
\hline & & 20 & $3.6 \pm 0.20$ & $2.6 \pm 0.30$ & $3.6 \pm 0.35$ & $3.4 \pm 0.45$ & $3.0 \pm 0.42$ \\
\hline & & 25 & $3.6 \pm 0.20$ & $2.2 \pm 0.18$ & $3.1 \pm 0.32$ & $3.2 \pm 0.43$ & $2.6 \pm 0.36$ \\
\hline & \multirow{5}{*}{ СPP } & 0 & $3.5 \pm 0.24$ & $2.9 \pm 0.44$ & $4.5 \pm 0.15$ & $4.5 \pm 0.24$ & $4.5 \pm 0.24$ \\
\hline & & 10 & $3.4 \pm 0.17$ & $3.6 \pm 0.17$ & $3.5 \pm 0.35$ & $3.4 \pm 0.23$ & $3.6 \pm 0.36$ \\
\hline & & 15 & $3.3 \pm 0.18$ & $3.4 \pm 0.17$ & $3.4 \pm 0.35$ & $3.3 \pm 0.18$ & $3.1 \pm 0.24$ \\
\hline & & 20 & $3.3 \pm 0.15$ & $3.4 \pm 0.20$ & $3.0 \pm 0.33$ & $2.9 \pm 0.32$ & $2.8 \pm 0.34$ \\
\hline & & 25 & $3.1 \pm 0.26$ & $3.3 \pm 0.29$ & $2.6 \pm 0.28$ & $2.7 \pm 0.31$ & $2.4 \pm 0.36$ \\
\hline \multirow{10}{*}{ 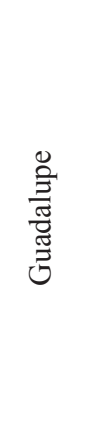 } & \multirow{5}{*}{ PPP } & 0 & $4.3 \pm 0.32$ & $4.5 \pm 0.20$ & $4.9 \pm 0.10$ & $4.6 \pm 0.18$ & $4.8 \pm 0.14$ \\
\hline & & 10 & $3.9 \pm 0.28$ & $3.9 \pm 0.30$ & $4.3 \pm 0.24$ & $3.8 \pm 0.26$ & $4.1 \pm 0.32$ \\
\hline & & 15 & $3.9 \pm 0.30$ & $3.4 \pm 0.20$ & $4.1 \pm 0.25$ & $3.5 \pm 0.31$ & $3.9 \pm 0.35$ \\
\hline & & 20 & $3.4 \pm 0.17$ & $2.7 \pm 0.15$ & $3.8 \pm 0.31$ & $3.3 \pm 0.38$ & $3.2 \pm 0.32$ \\
\hline & & 25 & $3.2 \pm 0.15$ & $2.0 \pm 0.24$ & $3.3 \pm 0.38$ & $3.1 \pm 0.42$ & $2.6 \pm 0.35$ \\
\hline & \multirow{5}{*}{ CPP } & 0 & $4.3 \pm 0.32$ & $4.5 \pm 0.20$ & $4.9 \pm 0.10$ & $4.6 \pm 0.18$ & $4.8 \pm 0.14$ \\
\hline & & 10 & $3.7 \pm 0.15$ & $4.2 \pm 0.10$ & $3.7 \pm 0.41$ & $3.4 \pm 0.23$ & $3.8 \pm 0.26$ \\
\hline & & 15 & $3.7 \pm 0.15$ & $4.1 \pm 0.10$ & $3.6 \pm 0.34$ & $3.3 \pm 0.18$ & $3.3 \pm 0.15$ \\
\hline & & 20 & $3.4 \pm 0.23$ & $3.8 \pm 0.15$ & $3.4 \pm 0.23$ & $3.0 \pm 0.29$ & $3.0 \pm 0.19$ \\
\hline & & 25 & $3.1 \pm 0.30$ & $3.3 \pm 0.30$ & $2.8 \pm 0.31$ & $2.7 \pm 0.31$ & $2.7 \pm 0.26$ \\
\hline
\end{tabular}

All data are the mean \pm SE of five replicates.

PPP: Pumpkin Pomace Powder, CPP: Carrot Pomace Powder. 
In general, a regular decline was observed in the crust color values of all cookie samples except for Gerek-79 supplemented with PPP. Depending on the addition of PPP, the crust color of cookies which prepared from this flour sample showed a little improvement, but it was not observed a significant change in the crust color in comparison with the addition level. Texture and taste scores of cookies which were given by panelists, decreased depending on the level of PPP or CPP in formulation, however a significant variation was not observed in the samples supplemented with the low levels respect to control. It was also observed a regular decline in the scores of overall acceptability depending on the increasing fiber levels. According to the sensory evaluation by the panelists, the cookies containing higher levels of PPP and CPP were found acceptable.

\section{Conclusion}

Addition of PPP and CPP as a source of dietary fibre to wheat flour effected the dough characteristics in various ways. The present study demonstrated that the PPP and CPP used to enhance dietary fiber content of cookies made from two different wheat flour showed an important effects of dough characteristics. Incorporation PPP or CPP into cookie dough systems increased water absorption, dough development time, stability and decreased softening degree of dough as measured by farinograph. These properties generally refer to a dough's mixing and handling properties during processing. While brightness (L value) of cookies decreased depending on incorporation PPP and CPP, redness (a value) increased. Incorporation of different pomace powders showed a different effect on yellowness (b value) which was increased slightly by PPP but was decreased by CPP. While the spread ratio of cookies was decreased, breaking strength of cookies was increased by the supplementation of pumpkin and carrot pomace powders. It was observed that negative effect of PPP on the overall acceptability is less than that of CPP. However, PPP addition more affected the breaking strength values than CPP. It can be concluded that acceptable cookie samples can be prepared by supplementing PPP and CPP in both flours without affecting their overall acceptability. In addition, this study is very important to show the way of putting the by- product the carrot juice process to good use in bakery industry. Therefore, PPP and CPP have a great potential to be used as functional ingredients in cookie formulations and to improve nutraceutical properties of cookies.

Acknowledgements The authors would like to thank The Scientific and Technological Research Council of Turkey (TUBITAK, Project No:20080745004) and Ankara University Scientific Research Projects (BAP, Project No:107O798) for supporting this investigation.
The authors wish also to thank Ulker Co. (Ankara, Turkey) for providing some cookie ingredients.

\section{References}

AACC (2002). Approved Methods of American Association of Cereal Chemists (AACC). The Association: St. Paul, MN.

Ajila, C.M., Leelavathi, K. and Prasada Rao, U.J.S. (2008). Improvement of dietary fiber content and antioxidant properties in soft dough biscuits with the incorporation of mango peel powder. J. Cereal Sci., 48(2), 319-326.

Alasalvar, C., Grigor, J.M., Zhang, D., Quantick, P.C. and Shahidi, F. (2001). Comparison of volatiles, phenolics, sugars, antioxidant vitamins, and sensory quality of different colored carrot varieties. J. Agric. Food Chem., 49, 1410-1416.

Anonymous (2002). Chroma meter CR-400/410 instruction manuel. Konica Minolta Sensing, Inc, Japan.

AOAC (2000). Official Methods of Analysis. $17^{\text {th }}$ ed., Association of Official Analytical Chemists, Gaithersburg, MD, USA.

Arora, A. and Camire, M.E. (1994). Performance of potato peels in muffins and cookies. Food Res. Int., 27, 15-22.

Arshad, M.U., Anjum, F.M. and Zahoor, T. (2007). Nutritional assessment of cookies supplemented with defatted wheat germ. Food Chem., 102, 123-128.

Aziah, A.A.N. and Komathi, C.A. (2009). Physicochemical and functional properties of peeled and unpeeled pumpkin floor. $J$. Food Sci., 74, 328-333.

Caili, F., Haijun, T., Tongyi, C., Yi, L. and Quanhong, L. (2007). Some properties of an acidic protein-bound polysaccharide from the fruit of pumpkin. Food Chem., 100, 944-947.

Cao, G., Sofic, E. and Prior, R.L. (1996). Antioxidant capacity of tea and common vegetables. J. Agric. Food Chem., 44, 34263431 .

Chantaro, P., Devahastin, S. and Chiewchan, N. (2008). Production of antioxidant high dietary fiber powder from carrot peels. $L W T$, 41, 1987-1994.

Chau, C., Chen, C. and Lee, M. (2004). Comparison of the characteristics, functional properties, and in vitro hypoglycemic effects of various carrot insoluble fiber-rich fractions. $L W T, 37,155-160$.

Dikeman, C.L. and Fahey, G.C. (2006). Viscosity as related to dietary fibre: A review. Crit. Rev. Food Sci. Nutr., 46, 649-663.

Eim, V.S., Simal, S., Roselló, C. and Femenia, A. (2008). Effects of addition of carrot dietary fibre on ripening process of a dry fermented sausage (sobrassada). Meat Science, 80, 173-182.

Esclada Pla, M.F., Ponce, N.M., Stortz, C.A., Gerschenson, L.N. and Rojas, A.M. (2006). Composition and functional properties of enriched fiber products obtained from pumpkin (Cucurbita moschata Duchesne ex Poiret). LWT, 40, 1176-1185.

Evageliou, V., Ptitchkina, N.M. and Morris, E.R. (2005). Solution viscosity and structural modification of pumpkin biopectin. Food Hydrocolloids, 19, 1032-1036. 
Figuerola, F., Hurtado, M.L., Estévez, A.M., Chiffelle, I. and Asenjo, F. (2005). Fibre concentrates from apple pomace and citrus peel as potential fibre sources for food enrichment. Food Chem., 91, 395-401.

Gaines, C.S. (1991). Objective measurements of the hardness of cookies and crackers. Cereal Foods World, 36, 989.

Gliemmo, M.F., Latorre, M.E., Gerschenson, L.N. and Campos, C.A. (2009). Color stability of pumpkin (Cucurbita moschata, Duchesne ex Poiret) puree during storage at room temperature: Effect of $\mathrm{pH}$, potassium sorbate, ascorbic acid and packaging material. LWT, 42, 196-201.

Gómez, M., Ronda, F., Blanco, C.A., Caballero, P.A. and Apesteguía, A. (2003). Effect of dietary fibre on dough rheology and bread quality. Eur. Food Res. Technol., 216, 51-56.

ICC (2002) International Cereal Science and Technology Associaation, Vienna, Austria.

Jaime, L., Mollá, E., Fernández, A., Mártin-Cabrejas, M., López Andreu, F. and Esteban, R. (2002). Structural carbohydrates differences and potential source of dietary fiber of onion (Allium cepa L.) tissues. J. Agric. Food Chem., 50, 122-128.

Jun, H., Lee, C.H., Song, G.S. and Kim, Y.S. (2005). Characterization of the pectic polysaccharides from pumpkin peel. $L W T, \mathbf{3 9}$, 554-561.

Larrea, M.A., Chang, Y.K. and Martinez-Bustos, F. (2005). Some functional properties of extruded orange pulp and its effect on the quality of cookies. $L W T, \mathbf{3 8}, 213-220$.

Lee, C., Cho, J.K., Lee, S.J., Koh, W., Park, W. and Kim, C.H. (2002). Enhancing $\beta$-carotene content in asian noodles by adding pumpkin powder. Cereal Chem., 79, 593-595.

McWatters, K.H., Ouedraogo, J.B., Resurrection, A.V.A., Hung, Y.C. and Philips, R.D. (2003). Physical and sensory characteristics of sugar cookies containing mixtures of wheat, fonio (Digitaria exilis) and cowpea (Vigna unguiculata) flours. Int. J. Food Sci. Tech., 38, 403-410.

Özkaya, H. and Özkaya, B. (2005). Tahıl ürünleri ve analiz yöntem- leri. $2^{\text {nd }}$ ed. Ankara: Gıda teknolojisi derneği yayınları. 157 p.

Pongjanta, J., Naulbunrang, A., Kawngdang, S., Manon, T. and Thepjaikat, T. (2006). Utilization of pumpkin powder in bakery products. Songklanakarin J. Sci. Technol., 28, 71-79.

Ptitchkina, N.M., Novokreschonova, L.V., Piskunova, G.V. and Morris, E.R. (1998). Large enhancements in loaf volume and organoleptic acceptability of wheat bread by small additions of pumpkin powder: possible role of acetylated pectin in stabilising gas-cell structure. Food Hydrocolloids, 12, 333-337.

Rehman, Z., Islam, M. and Shah, W.H. (2003). Effect of microwave and conventional cooking on insoluble dietary fibre components of vegetables. Food Chem., 80, 237-240.

Rosell, C.M., Santos, E. and Collar, C. (2009). Physico-chemical properties of commercial fibres from different sources: a comparative approach. Food Res. Int., 42, 176-184.

Schneeman, B. (1987) Soluble vs insoluble fiber-different physiological responses. Food Technol., 41, 81-82.

Seker, I.T., Ozbas, O.O., Gokbulut, I., Ozturk, S. and Koksel, H. (2009). Effects of fiber-rich apple and apricot powders on cookie quality. Food Sci. Biotechnol., 18, 948-953.

Sudha, M.L., Baskaran, V. and Leelavathi, K. (2007a). Apple pomace as a source of dietary fiber and polyphenols and its effect on the rheological characteristics and cake making. Food Chem., 104, 686-692.

Sudha, M.L., Vetrimani, R. and Leelavathi, K. (2007b). Influence of fibre from different cereals on the rheological characteristics of wheat flour dough and on biscuit quality. Food Chem., 100,13651370.

Vinson, J.A., Hao, Y., Su, X. amd Zubik, L. (1998). Phenol antioxidant quantity and quality in foods: vegetables. J. Agric. Food Chem., 46, 3630-3634.

Yoon, K.Y., Cha, M., Shin, S.R. and Kim, K.S. (2005). Enzymatic production of a soluble-fibre composition. Food Chem., 92, 151157. 